\title{
Future Teachers Forming Professional Expectations in Modern Educational Conditions
}

\section{Formación de Expectativas Profesionales de Futuros Educadores en Entornos Educativos Modernos}

\author{
Irina Aleksandrovna Yudina* \\ M.K. Ammosov North-Eastern Federal University, Yakutsk, Russia \\ ORCID: https://orcid.org/0000-0002-9641-5088 \\ Evdokia Anatolievna Neustroeva \\ M.K. Ammosov North-Eastern Federal University, Yakutsk, Russia \\ ORCID: https://orcid.org/0000-0002-1534-1639 \\ Tatiana Alekseevna Makarova \\ Churapchinsky State Institute of Physical Culture and Sports, Churapcha, Russia \\ ORCID: https://orcid.org/0000-0001-6015-8799 \\ Anna Afanasyevna Fedorova \\ Pre-school Educational Institution "Integrated Kindergarten No. 88", Churapcha, Russia \\ ORCID: https://orcid.org/0000-0002-9796-6009
}

Received 07-03-20 Revised 07-30-20 Accepted 09-13-20 On line 09-23-20

*Correspondence

Email: irina.a.yudina@inbox.ru
Cite as:

Yudina, I.A., Neustroeva, E. A., Makarova, T. A., \& Fedorova, A. A. (2020). Future Teachers Forming Professional Expectations in Modern Educational Conditions. Propósitos y Representaciones, 8(SPE3), e720. Doi: http://dx.doi.org/10.20511/pyr2020.v8nSPE2.720 


\section{Summary}

The relevance of the present study lies in improving the training of future teachers, an issue of particular importance during a pandemic. The authors aim to identify the level of professional expectations of future teachers and determine the necessary conditions for them to be upgraded. Study objective: The study was focused on evaluating the level of professional expectations of future teachers (PEFT) and revealing conditions catering for its improvement. Methodology: Both theoretical and empirical methods were used in the study: based on literature review the authors compiled PEFT components (motivational, emotional, cognitive, and value-semantic) and the substantial characteristics of these components were listed. In accordance with the selected components, a questionnaire was designed to identify the actual level of professional expectations among students. The experiment results were analyzed both qualitatively and quantitatively. Experiment results: The study reveals the role of professional expectations in raising the efficiency of teachers' professional activities. PEFT components and substantial features have been established. Recommendations are provided to elicit positive PEFT formation using the University educational environment. The practical implications of the study: The nuances of professional expectations development among future teachers have been identified. When organizing professional education, these nuances should be considered for increased effectiveness and for greater success of graduates in their professional activities.

Keywords: Future Teachers; Professional Expectations; Professional Education; Professional Activity; Distant Learning Technology.

\section{Resumen}

La pertinencia de este estudio se debe al desafío de mejorar la formación de los futuros educadores, que cobra especial importancia en el contexto de una pandemia. El artículo describe la técnica y los resultados de un experimento para identificar el nivel de expectativas profesionales de los futuros educadores. El objetivo del estudio: identificar el nivel de expectativas profesionales de los futuros educadores e identificar las condiciones que contribuyen a su aumento. Métodos de investigación: este estudio se llevó a cabo utilizando métodos teóricos y empíricos: sobre la base del análisis de la literatura, se determinaron los componentes de las expectativas profesionales de los futuros educadores, se realizó un cuestionario utilizando el cuestionario desarrollado, se realizó un análisis cuantitativo y cualitativo de los resultados del experimento. Resultados del estudio: se revela el papel de las expectativas profesionales en la mejora del desempeño profesional de los educadores. Se definen los componentes de las expectativas profesionales de los futuros educadores y se presentan sus características significativas. De acuerdo con los componentes seleccionados, se ha desarrollado un cuestionario para estudiantes con el objetivo de identificar su nivel de expectativas profesionales. Se presentan recomendaciones para la formación de expectativas profesionales positivas en los futuros educadores con recursos del entorno educativo de la Universidad. Importancia del estudio: se han identificado las características de la formación de expectativas profesionales de los futuros maestros, cuya consideración en la organización de la educación profesional contribuirá a aumentar su efectividad, el éxito de los graduados en la actividad profesional.

Palabra clave: Futuros educadores, expectativas profesionales, educación profesional, actividades profesionales, tecnología de educación a distancia. 


\section{Introduction}

The Russian education system at the present stage is marked by modernization processes due to social and economic changes occurring in the society. This circumstance justifies enhanced requirements to teachers.

Teacher-training colleges and universities are challenged to train competitive, competent, responsible specialists being ready for professional growth, social and professional mobility, including coping with a pandemic context. The competency building approach implemented currently in the system of higher professional education is aimed at development a comprehensive personal resource in students to enable an effective interaction with surrounding community and an efficient professional activity. However, not all graduates of pedagogical universities are successful in their professional activities, and it is largely due to the level of their professional expectations. In the article we assume that successfulness degree in one's professional activity is determined by availability and maturity of professional expectations in students (Shalimova, 2014). Research in PEFT will enable affecting this process with resources of University educational environment.

The issue of PEFT development related to enhancing success in pedagogical professional activities has been understudied. The study objective is assessment of professional expectations' maturity in future teachers and outlining conditions catering for their improvement

While preparing this article, the following tasks were set: to reveal the relevance of PEFT level increase to enhance professional success; to explore the theoretical aspect of the problem; to analyze results of the experiment that was focused on revealing PEFT levels; to propose recommendations for maturing positive PEFT generation using resources of a University educational environment.

\section{Literature Review}

The analysis of publications on the study subject allowed identifying various approaches to the meaning of "expectation" concept that does not have a single definition in psychological theory so far, but we came across various interpretations of this concept. In our study, we rely on Victor Vroom's expectancy theory of motivation, based on the assumption that people make their efforts to achieve a goal only when they are sure that their needs are most likely to be met. We regard as significant for us the research by A.V. Tyszkowski who interprets expectations as a complex cognitive-motivational structure determining behavioral orientation and regulation of an individual who is regarded as a subject of behavior in an actual situation (Tyszkowski, 1999). The study is based on understanding social and professional expectations being elements of professional identity formation (Petrovsky, 1987). The study is also based on the definition of social expectations as a process of expecting an individual to fulfill his or her social role (Yaroshevsky, Petrovsky, 2002). From the above, we can conclude that expectations are complex, multidimensional, dynamic formations related to future and linked to one's opinion of possible situation development scenarios.

Based on results of her research, Shalimova A. M. defines professional expectations as a set of individual's ideas about his/her professional future mediated by personal and surrounding social and psychological factors (Shalimova, 2014). Examining PEFT formation, we turned to studies by foreign authors in this issue. 
In view of our research, the article by Kyriacou C., Kunc R., Stephens P., Hultgren A. (2003) is of special interest. The authors examine expectations of future teachers regarding their upcoming professional activity and highlight that research in professional expectations of future teachers will help to explain the reasons underlying the urgent problems of teachers' employment and retention in profession in many countries worldwide.

The study by Leijen Ä., Kullasepp K. (2016) examines the process of teachers' professional identity formation. The role of personal qualities of a teacher in this process is emphasized. The authors note that study outcomes should be reflected while developing programs for professional education and continuous professional training.

Schepens A., Aelterman A., Vlerick P. (2009) consider demographic characteristics, personal qualities, experience, and teacher-training context to be the most important aspects of professional identity formation.

In turn, Deng L., Zhu G., Li G., Xu Z. (2018) touch upon the emotional aspect of the process of future teachers' professional identity formation during practical training internships. The authors stress the importance of resolving contradictions that future teachers face during their practical training to develop their professional identity and obtaining a high-quality training.

The paper by Boudersa N. (2016) discusses the problem of quality of training teachers as an indicator of educational system effectiveness. The author emphasizes that scientific and theoretical training of future teachers and efficient professional development programs give rise to improving the quality of training teachers and cater for innovative processes in education.

From the research results obtained by Lee J., Turner J. (2016) it is possible to conclude that to facilitate and to contribute using strategies of self-regulation and learning by teachers in the learning process before they start their professional activities, a prospective teacher shall have both an internal motivation for professional training and a relevant understanding in what way their training is related to their future career goals.

Within the scope of our study, of special interest is the article by Herrington A. (2004). The author draws attention to difficulties encountered by teachers during transition from academic studies at a University to professional activity. Recent research on possibilities of the Internet in professional teachers' support are described, and some examples of successful online communities are provided.

The study by Manuel J. (2003) also concentrates on difficulties faced by a novice teacher during transition from a student to a professional, and the strategies are established aimed at enhancing the efficiency of this process.

Analysis of papers by Russian authors show that successful professional activity is an outcome of adequate to reality students' professional expectations, and however, inadequate or not fully matured professional expectations can cause professional failure (Shalimova, 2014).

During University studies, the process of professional expectations formation is affected by the environment in which the future teacher is developing, including the learning environment and technologies used.

To meet the up-to-date requirements tailored to society needs and opportunities of modern technologies, education quality improvement occurs due to using information and communication technologies, including distance education technologies, guided by the principle of free and flexible educational process catering for education openness, easy access to it, and economic efficiency (Boronenko, Fedotova, 2015; Kedrova, Muromtsev, 2017). 
In articles published in foreign journals by teachers of the Department of Informatics and Computer Engineering at Teacher Training Institute of M. K. Ammosov North-Eastern Federal University, it is reported that teachers began the educational process in e-learning format using distant education technologies, various ways of e-learning content delivery, and a wide range of tools and services for communication between students and teachers in electronic educational environment (Barakhsanova, Vlasova, Golikov, Prokopyev, Burnachov, Kuzin, 2017; Barakhsanova, Varlamova, Vlasova, Nikitina , Prokopyev, Myreeva, 2018; Kornilov, Danilov, Kornilov, Kovtun, 2017).

Due to the threat of the new coronavirus spread at the territory of the Russian Federation, students are educated on the basis of remote educational technologies. Within a short period, teachers and students found themselves in a situation of complete transition to distance education. It caused a number of problems, but also enabled gaining a valuable experience by all subjects of educational process. Thus, teachers within a short time have mastered new roles of coordinators, consultants, and tutors (Polyakova, 2020). In their turn, students have actually become subjects of the educational process who take an active part in structuring their own learning process.

We argue that in a pandemic context, the professional education dramatically changes the teaching situation at educational institutions and affects the process of PEFT formation

\section{Methodology and Methods}

Proceeding from the analysis of scientific, psychological and pedagogical literature, we have identified the following PEFT components: motivational, emotional, cognitive, and valuesemantic, and outlined their content-related characteristics:

- Motivational component is a group of motives expressing the established needs of an individual: cognitive and social motives, motives for professional development and future career promotion, pragmatic motives reflecting a material incentive of individuals in results of their professional activities;

- Emotional component comprises person's emotional and evaluative attitude to future profession that reflects a subjective vision of professional activities. This component can be positively filled with satisfaction and confidence in the choice of profession or in the desired result, and negatively filled if the outcome is undesirable or no satisfaction in activities or choices are felt;

- Cognitive component is formation of ideas about the future profession and selfrepresentation as a subject of social activity, the level of theoretical and practical readiness for professional activity;

- Value-semantic component comprises the image in subject's consciousness of values recognized by him as strategic life goals and general worldview orientations, and correlation of personal values and disposition with professional ones.

To explore PEFT level, a questionnaire was developed in accordance with the components of professional expectations defined by us. The questionnaire included questions to explore students' attitude to using distance learning technologies in educational process and their impact on education quality. The questionnaire results were estimated by points summed up to determine the PEFT level based on selected components of professional expectations 


\section{Population and Sample}

The empirical study of professional expectations was conducted on the basis of the Federal State Budgetary Educational Institutions of Higher Education "M. K. Ammosov North-Eastern Federal University" and "Churapchinsky State Institute of Physical Culture and Sports". The study was participated by 313 respondents, including 273 students majoring in: Pedagogical Education, Psychological and Pedagogical Education, Special (defectological) education at different levels of higher education. The number of participants by years: Bachelor's programme Year 1 - 51, Year 2 - 55, Year 3 - 34, Year 4 - 41, Year 5 -36; Master's programme Years 1\& 2 $-\mathrm{a}$ total of 56 persons. Novice teachers were also interviewed (40 persons in total). The sample comprised 298 girls and 15 boys aged from 17 to 30 .

\section{Analysis of Data}

The results of questionnaire survey showed that most respondents, namely $81.9 \%$, claim that they receive the professional education in priority to them. It is worth mentioning that $79.1 \%$ of respondents expressed their intention to work in the specialty they had been trained in at the University, $49.7 \%$ of them consider the profession selected to be their calling. The main value of pedagogical education was defined by students as "universality of knowledge" and "benefits for society". These values were chosen by students as follows: more than $60.7 \%$ - by Year 1 students, 63.6 - by Year 2, 55.8\% - by Year 3, over $71.4 \%$ of graduates and over $73.2 \%$ of Masters. $58.6 \%$ of all respondents have a clear idea about their future place of work.

The answers as to preferred type of institution were distributed as follows: state educational institutions were found the most popular, they were chosen by $59.9 \%$ of respondents, $12.7 \%$ plan to be employed as individual businessmen, and $4.1 \%$ plan to work at commercial institutions. At the same time, $23.3 \%$ of respondents chose the variant "does not matter" evidencing for them not to have made decision about their employment.

Among the criteria determining the choice of a future job, the key ones were "salary" $69.2 \%$, "social environment (team, possibility of interpersonal communication at work)" $-59 \%$, "job in their degree field" - 51\%. Less significant criteria were "job position" - $27.4 \%$, "close location of job site to home place" - 19.4\%.

The answers about knowledge and skills obtained at the University for working in the teaching field were distributed as follows: $46.2 \%$ believe that they have sufficient knowledge and skills for work, $44 \%$ of respondents consider it necessary to expand their knowledge and to improve their skills, $9.8 \%$ were undecided. $49.4 \%$ of respondents reported that they lack sufficient communication skills and interaction with students (children/teenagers), $33.1 \%$ believe that their knowledge of a professional foreign language is poor, $29.6 \%$ of respondents experience problems with research work, $27.1 \%$ noted deficient knowledge of specialized computer programs.

Mentioning their plans of knowledge extension in their professional area, $27.6 \%$ of respondents engaged in Bachelor programs plan to continue their education in Master's programs, $6.9 \%$ were undecided; $39.1 \%$ of Master's students plan to study at upgrade training course, $15.9 \%$ of them plan self-education activities; $10 \%$ of novice teachers plan professional retraining courses.

Competencies important for teaching practically equal number of respondents defined as the ability to apply theoretical knowledge in professional activities $-80.7 \%$ and teacher's practical skills $-80.3 \%$. $67.6 \%$ of respondents have an idea about job responsibilities in their professional area, $30.2 \%$ - are not fully aware, and $2.2 \%$ have no idea about their future profession. 
When asked about the most important factors affecting future specialist formation, $56.9 \%$ of all respondents rank first the maximum number of pedagogical practices in educational process, second (38.9\% of respondents) came personal features of University teachers. Nearly the same preference scores from respondents were received by arrangement of extracurricular, socially significant projects, events in professional activity area (University reunions, volunteering, social promotions, etc.) - $34.4 \%$ and active participation of students in scientific research activities $-34.4 \%$. The bottom score was obtained by University material equipment $-24.2 \%$.

The advantages of their future profession were evaluated by respondents as follows: creativity and consistent personal growth $-79.4 \%$, an opportunity to engage in tutoring and private practice- $52.9 \%$, long summer holidays $-42.4 \%$, work with young people $-42.1 \%$.

The key disadvantages of their future profession were listed as follows: a lot of preparatory activities in off-duty hours- $65.7 \%$, a small salary $-60.9 \%$, regular stress $-53.9 \%$, constant repeating the same information $-24.8 \%$, irregular working hours $-12.1 \%$, and dealing with at-risk teenagers $-3.1 \%$.

Thus, the obtained answers outline the general condition of professional expectations of students completing bachelor's and master's programs, as well as of young professionals.

\section{Results}

To summarize the survey results, we split the levels of professional expectations of future teachers into positive, neutral, and negative, and determined indicators for each level comprised the above components.

Description of each professional expectations level is presented in Table 1.

Table 1.

Indicators of future teachers' professional expectations

\begin{tabular}{|c|c|c|c|c|}
\hline \multirow{2}{*}{$\begin{array}{l}\frac{a}{0} \\
\frac{u}{u}\end{array}$} & \multicolumn{4}{|c|}{ PROFESSIONAL EXPECTATIONS COMPONENTS } \\
\hline & Motivational & Emotional & Cognitive & Value-semantic \\
\hline 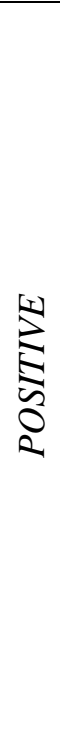 & $\begin{array}{l}\text { - Seeking for } \\
\text { constant } \\
\text { intellectual } \\
\text { and spiritual } \\
\text { growth; } \\
\text { - Aspiration to } \\
\text { improve the } \\
\text { general } \\
\text { cultural level } \\
\text { via } \\
\text { professional } \\
\text { knowledge; } \\
\text { - } \\
\text { Predominance } \\
\text { of professional } \\
\text { development } \\
\text { motives }\end{array}$ & $\begin{array}{l}\text { - Positive attitude } \\
\text { (optimistic } \\
\text { perception) to both } \\
\text { professional activity } \\
\text { and the entire } \\
\text { professional training; } \\
\text { - Commitment to } \\
\text { professional success; } \\
\text { - Confidence in } \\
\text { selecting the right } \\
\text { profession }\end{array}$ & $\begin{array}{l}\text { - High maturity } \\
\text { level of ideas about } \\
\text { the future profession } \\
\text { and oneself as a } \\
\text { subject of social } \\
\text { activity; } \\
\text { - High level of } \\
\text { theoretical and } \\
\text { practical readiness } \\
\text { for professional } \\
\text { activity; }\end{array}$ & $\begin{array}{l}\text { - Availability of } \\
\text { mindful priorities } \\
\text { in life and } \\
\text { professional values; } \\
-\quad \\
\text { correlation Distinct } \\
\text { personal of and } \\
\text { professional values }\end{array}$ \\
\hline$\sum_{\substack{x \\
z}}^{\frac{k}{2}}$ & $\begin{array}{lr}- & \text { Vague } \\
\text { motives } & \text { of }\end{array}$ & $\begin{array}{l}\text { - Positive emotions } \\
\text { mainly inspired by }\end{array}$ & $\begin{array}{l}\text { - Blurred idea of the } \\
\text { future profession }\end{array}$ & $\begin{array}{l}\text { - Absence of } \\
\text { matured }\end{array}$ \\
\hline
\end{tabular}




\begin{tabular}{|c|c|c|c|c|}
\hline & $\begin{array}{l}\text { educational } \\
\text { activities; } \\
\text { - Prevailing of } \\
\text { pragmatic } \\
\text { motives; } \\
\text { - Focus on } \\
\text { receiving } \\
\text { higher } \\
\text { education }\end{array}$ & $\begin{array}{l}\text { external attributes of } \\
\text { professional activity } \\
\text { (social status, } \\
\text { material benefits, } \\
\text { etc.), and not } \\
\text { provided by } \\
\text { satisfaction from } \\
\text { teaching; } \\
\text { - Lack of } \\
\text { confidence in } \\
\text { selecting the right } \\
\text { profession }\end{array}$ & $\begin{array}{l}\text { and oneself as a } \\
\text { subject of social } \\
\text { activity; } \\
\text { - Varied level of } \\
\text { theoretical and } \\
\text { practical readiness } \\
\text { for professional } \\
\text { activity }\end{array}$ & $\begin{array}{l}\text { professional values, } \\
\text { - Prevailing of } \\
\text { values and interests } \\
\text { not related to } \\
\text { teaching }\end{array}$ \\
\hline 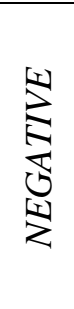 & $\begin{array}{l}\text { - Absence of } \\
\text { professional } \\
\text { motivation and } \\
\text { interest in } \\
\text { teaching }\end{array}$ & $\begin{array}{l}\text { - Negative attitude to } \\
\text { future profession and } \\
\text { the entire } \\
\text { professional training; } \\
\text { - Absence of } \\
\text { satisfaction provided } \\
\text { by teaching }\end{array}$ & $\begin{array}{l}\text { - Negative image of } \\
\text { future profession; } \\
\text { - Low level of } \\
\text { theoretical and } \\
\text { practical readiness } \\
\text { for professional } \\
\text { activity }\end{array}$ & $\begin{array}{l}\text { - Absence of } \\
\text { mindful matured } \\
\text { professional values; } \\
\text { - Prevailing of } \\
\text { values and interests } \\
\text { not related to } \\
\text { teaching }\end{array}$ \\
\hline
\end{tabular}

Based on the results, it can be concluded that the positive level of professional expectations is featured by determination and readiness for self-realization in professional teaching; the neutral level - by uncertainty about professional teaching activity, lack of confidence in selecting the right profession; the negative level - by determined by a negative attitude to future profession and lack of interest in teaching.

From the empirical study done, the following percentage of PEFT level distribution was found (the total percentage): positive (35.1\%), negative (22.7\%), and neutral $(42.2 \%)$. The distribution of results for each level of professional expectations by education levels and years of respondents' programs are presented in Table 2.

Table 2.

Results of the study on professional expectations levels

\begin{tabular}{l|c|c|c|c|c|c|c|c|c}
\hline $\begin{array}{l}\text { Professional } \\
\text { expectations } \\
\text { levels }\end{array}$ & $\begin{array}{c}\text { Total } \\
\text { percentage }\end{array}$ & \multicolumn{4}{|c|}{ Bachelors' programs } & \multicolumn{2}{c|}{$\begin{array}{c}\text { Masters' } \\
\text { programs }\end{array}$} & $\begin{array}{c}\text { Novice } \\
\text { teachers }\end{array}$ \\
\cline { 2 - 11 } & & Year 1 & Year 2 & Year 3 & Year 4 & Year 5 & Year 1 & Year 2 & \\
\cline { 2 - 10 } & & $\begin{array}{c}51 \\
\text { pers. }\end{array}$ & $\begin{array}{c}55 \\
\text { pers. }\end{array}$ & $\begin{array}{c}34 \\
\text { pers. }\end{array}$ & $\begin{array}{c}41 \\
\text { pers. }\end{array}$ & $\begin{array}{l}36 \\
\text { pers. }\end{array}$ & $\begin{array}{c}25 \\
\text { pers. }\end{array}$ & $\begin{array}{c}31 \\
\text { pers. }\end{array}$ & $\begin{array}{c}40 \\
\text { pers. }\end{array}$ \\
\hline Positive & $35.1 \%$ & $11.8 \%$ & $16.4 \%$ & $17.6 \%$ & $24.3 \%$ & $33.3 \%$ & $64 \%$ & $70.9 \%$ & $72.5 \%$ \\
\hline Neutral & $42.2 \%$ & $52.9 \%$ & $52.7 \%$ & $58.8 \%$ & $53.8 \%$ & $47.3 \%$ & $20 \%$ & $16.1 \%$ & $17.5 \%$ \\
\hline Negative & $22.7 \%$ & $35.3 \%$ & $30.9 \%$ & $23.6 \%$ & $21.9 \%$ & $19.4 \%$ & $16 \%$ & $13 \%$ & $10 \%$ \\
\hline
\end{tabular}

The positive PEFT level was found in $35.1 \%$ of all respondents, and values for each group at this level have significant differences, for example, undergraduate students of Year 1$11.8 \%$, Year $5-33 \%$. The number of students with a positive level rises by graduate courses. In Masters' group the share of students with a positive level of professional expectations is significantly higher than among Bachelor students: 64\% and 70.9 for Years 1 and 2, respectively. Among novice teachers, the positive level percentage is the highest in the sample $72.5 \%$.

Most respondents showed a neutral level of professional expectations - 42.2\%. It should be noted that this level was found in nearly half of Bachelor students: Year 1-52.9\%, Year 2 $52.7 \%$, Year 3-58.8\%, Year 4-53.8\%, Year 5-47.3\%. In Masters' group the neutral level percentage is much lower: Year $1-20 \%$ and Year $2-16.1 \%$, being similar to its level in novice teachers' group - $17.5 \%$. 
The negative professional expectations level was found in the least number of respondents $-22.7 \%$. Distribution of negative level students by years of study shows a steady decline by the final year (see the table above)ю In Masters' group the negative level percentage is lower than the one of Bachelors' group, and decreases by training completion: Year $1-16 \%$, Year $2-13 \%$. Among novice teachers, the percentage of respondents with a negative level is the least $-10 \%$.

The survey results indicate that Bachelor students manifest a gradual increase in the share of respondents with a positive PEFT level and a decrease in the share of respondents with a negative level, and the neutral level share stays relatively stable and significant.

PEFT dynamics observed in students majoring in Special (defectological) education is more distinct, which is due to the specific nature of PEFT formation in future teachersdefectologists justified by the maturity degree of professional awareness and professional value orientations. These results are consistent with the opinion by Vodennikova L. A. on this issue (Vodennikova, 2015).

The overall majority of Master's students have a positive PEFT level for their commitment and readiness for self-realization in teaching. The percentage of students with a neutral and negative level is less significant and comes down by the final year.

Naturally, the best PEFT values are found in novice teachers. However, a certain number of respondents in this group revealed neutral and negative levels of professional expectations.

We relate the results obtained to goal-oriented activities to improve the quality of future teachers training bearing in mind the needs of regional educational environment (Yudina, Abramova, Kornilova, 2017). We associate the results obtained with the purposeful work to improve the quality of training of future teachers, taking into account the needs of regional educational space (Yudina, Abramova, Kornilova, 2017), formation of future teachers ' readiness to teach children with disabilities in inclusive education, which is relevant for modern educational environment (Neustroyeva, Yudina, Kozhurova, Neustroyeva, Nikolayev, 2018).

Our findings provide the basis for establishing conditions influencing the enhancement of professional expectations level and for developing proposals to improve 2 positive PEFT using resources of University educational environment.

The questions about the efficiency of using distant educational technologies in training future teachers were answered as follows: $11.8 \%$ of respondents regard using distance learning technologies as efficient ones, $36.7 \%$ find them more efficient than not, 14.6 percent assume that distance education is inefficient rather than the reverse, 16.5 per cent affirmed ineffectiveness of distance education, and $20.4 \%$ were undecided. Considering advantages of distance education, $65.7 \%$ of respondents mention first freedom and flexibility (the possibility to plan the time, place and duration of classes on their own); $61.5 \%$ note that distance education is more accessible in view of independence from geographical and temporal location, and health condition; $48.8 \%$ evaluated the possibility of learning at an individual pace with the learning speed set by the student himself depending on his personal circumstances and needs; $37.6 \%$ highlighted mobility (effective feedback used between the teacher and the student); $30.6 \%$ noted technology (engaging the latest advances of information and telecommunication technologies in the educational process); approximately the same values $-21.3 \%$ and $21 \%$ were assigned to variability (a wide choice of educational programs and trainings) and creativity (comfortable conditions for student's creative self-expression). 
The disadvantages of distance education were identified by respondents as follows: $78.1 \%$ - lack of face-to-face contact (alive relationship ) between a teacher and students, $46.5 \%$ - insufficient possibility to develop practical professional skills in absence of direct interaction between students and other subjects of educational process (teachers, children, parents), $43 \%$ the need for appropriate technical equipment: a computer and Internet access; $37.3 \%$ - absence of distinct timing of educational process, the necessity of working long hours in front of the computer; $33.4 \%$ - the need for students to have developed personal qualities: self-discipline, independence and consciousness.

The results thus obtained within the research on using distance education technologies for professional training of future teachers demonstrated a wide variety of respondents' opinions about its efficiency. Besides, the respondents objectively assess the possibilities of using distance education and its advantages and disadvantages. These results, in our opinion, are justified by difficulties of active transition to distance education in the pandemic context and insufficient readiness on the part of students and teachers.

Our conclusions are in good agreement with the results of research conducted by Ignatiev V. P. and Arkhangelskaya E. A. at Ammosov North-Eastern Federal University. According to its outcomes, using effective software products: SED Moodle, Zoom, Skype, WhatsApp messenger, Instagram, etc. for remote work by teachers is believed to be effective by a significant number of students (Ignatiev, Archangelskaya, 2020)

\section{Discussion}

The survey results analysis indicate that conditions of increasing the level of professional expectations of future teachers include: he maximum number of pedagogical practices in educational process, the role teacher's personality, arrangement of extracurricular, socially significant projects, events in professional activity area (University reunions, volunteering, social promotions, etc.), active participation of students in scientific research activities, and University material equipment.

The increase in the number of students with a positive level of professional expectations by the final year, in our opinion, occurs largely due to saturation of educational process with students' practical activities and implementation of socially important projects on the basis of the University and its social partners. Participation of students in design and implementation of such projects caters for formation of motives for professional development, helps to realize the social and personal significance of future profession, and develops the system of conscious priorities of professional and life values (Bozhedonova, Vasileva, Nogovitsyna, Yudina, 2018; Yudina, Stepanova, 2019; Manasytova, Makarova, 2018).

To develop professional value guides in future special education teachers, Vodennikova L. A. reasonably suggests providing tutors' support to students' learning activities to arrange interaction between educational environment subjects, to form and support educational and professional motivation, and to assist in organizing independent educational activities (Vodennikova, 2015).

We believe that performing coordinators' and tutors' functions by teachers enhances the educational process efficiency, especially when supported by extensive use of distance education technologies.

As we see it, students with a neutral and negative level of professional expectations require a careful attention to develop their positive professional expectations using resources of University educational environment. It will contribute to enhancing the efficiency of their professional activities in the future. 


\section{Conclusion}

Proceeding from the study, the components of professional expectations of future teachers have been specified, and their substantial characteristics have been described. In conformity to them, the levels of professional expectations have been identified.

The number of students with a positive level of professional expectations ensuring the efficiency of future professional activities, increases by the final year, but, nevertheless, it remains insufficient. This number can be increased by creating conditions for transition to the positive PEFT level of students from neutral and negative levels

The resources facilitating this transition are available in University educational environment that should be tailored to meet the following requirements:

1. To create conditions for gaining by students of practical experience in various areas (educational, scientific, social) and realization of their potential in outside environment, to ensure formation of their social activity that contributes to their successful personal growth and professional development.

2. To include elective courses in educational programs, to provide trainings, to fill the programs of disciplines, modules and practices with the appropriate content focused on formation of motives for professional development and of professional value guides.

3. To provide running events contributing to personal qualities development in students enabling their efficient participation in educational process using distance learning technologies, as well as facilitating their work under conditions of uncertainty, including pandemics, i.e. such qualities as self-discipline, independence, and consciousness.

4. To activate teachers' work as educational tutors to implement an individual trajectory of professional training and to coordinate the educational process in the context of distance education.

5. To create conditions for improving the general cultural level of students and developing seeking for constant intellectual and spiritual growth.

\section{References}

Barakhsanova, E.A., Varlamova, V.A., Vlasova, E.Z., Nikitina, E.V., Prokopyev, M.S., Myreeva, A.N. (2018). Vocational training of school teachers in yakutia's universities through the principle of regionalization (case study of the methodology of teaching natural science to prospective teachers). Espacios, 39(20), 35.

Barakhsanova, E.A., Vlasova E.Z., Golikov, A.I., Prokopyev, M.S., Burnachov, A.E., Kuzin, Z.S. (2017). Peculiarities of quality management of teachers' e-learning training in the arctic regions. Espacios, 38(55), 25.

Boudersa, N. (2016) The Importance of Teachers' Training Programs and Professional Development in the Algerian Educational Context: Toward Informed and Effective Teaching Practices. Expériences Pédagogic, 1.

Boronenko, T. A., Fedotova, V. S. (2015) Directions of training future teachers to use distance educational technologies in professional activities (praxiological aspect of the activity approach). Education and science, 3(122), 87-105, from https://cyberleninka.ru/article/n/napravleniya-podgotovki-buduschih-pedagogov-kispolzovaniyu-distantsionnyh-obrazovatelnyh-tehnologiy-v-professionalnoydeyatelnosti

Bozhedonova, A., Vasileva, A., Nogovitsyna, N., Yudina I. (2018) Developing social activity in students studying for a teaching degree. Revista Espacios, 39(40), 19. 
Deng, L., Zhu, G., Li, G., Xu, Z.(2018) Student Teachers' Emotions, Dilemmas, and Professional Identity Formation amid the Teaching Practicums. The Asia-Pacific Education Researcher, 27(2), from https://www.researchgate.net/publication/327106338_Student_Teachers'_Emotions_Dil emmas_and_Professional_Identity_Formation_Amid_the_Teaching_Practicums

Herrington, A. (2004) University to work transition: Implications for the evaluation and design of online communities of practice, from: https://www.researchgate.net/publication/242255139_University_to_work_transition_I mplications_for_the_evaluation_and_design_of_online_communities_of_practice

Manuel, J. (2003) 'Such are the Ambitions of Youth': Exploring issues of retention and attrition of early career teachers in New South Wales. Asia-Pacific Journal of Teacher Education. 31(2)

Ignatiev, V. P., Archangelskaya, E. A. (2020) Distance education through students' eyes (analysis of survey results among Federal University students). Modern Hi-Tech technologies, $\quad 6(1), \quad 138-142, \quad$ from $\quad$ http://www.toptechnologies.ru/ru/article/view?id=38083

Kedrova, G. E., Muromtsev, V. V. (2017) Current state and development directions of distance learning systems. Bulletin of RGGU. Series "Economy. Management. Law", 4, 88-101. Available at: https://cyberleninka.ru/article/n/sovremennoe-sostoyanie-i-napravleniyarazvitiya-sistem-distantsionnogo-obucheniya

Kornilov, I.V., Danilov, D.A., Kornilova, A.G., Kovtun, T.I. (2017) Methodical approaches to implementation of electronic educational technologies in professional academic teacher training. Man in India, 97 (15), 441-460. from https://www.scopus.com/inward/record.uri?eid=2-s2.085027307136\&partnerID=40\&md5=a7cbf961c655021751112e65dbc828ab

Kyriacou, C., Kunc, R., Stephens, P., Hultgren, A. Student Teachers Expectation of Teaching as a Career in England and Norway. Educational Review 55(3), from https://www.researchgate.net/publication/44836397_Student_Teachers'_Expectations_o f_Teaching_as_a_Career_in_England_and_Norway

Lee, J., Turner, J. (2016) The role of pre-service teachers' perceived instrumentality, goal commitment, and motivation in their self-regulation strategies for learning in teacher education courses. Asia-Pacific Journal of Teacher Education, 45:3, 213-228, DOI: https://doi.org/10.1080/1359866X.2016.1210082

Leijen, Ä., Kullasepp, K. Professional role expectations and related feelings when solving pedagogical dilemmas: a comparison of pre- and in-service teachers.(2015) Aivi Toompalu Department of Education and Special Education, University of Gothenburg, 307-323. Retrieved April 07, $2015 . \quad$ DOI: https://doi.org/10.1080/13664530.2016.1237985

Manasytova, M. A., Makarova, T. A. (2018) Creating pedagogical conditions for improving competence and competitiveness of extramural training students majoring in 44.03.01 "Pedagogical education" (Profile: Preschool education) based on cluster approach. Modern pedagogical education, 4, 129-132.

Neustroyeva, A. Yudina, I. Kozhurova, A. Neustroyeva, E. Nikolayev, E. (2018) Implementation of interdisciplinary projects in vocational training of future teachers for the education of children with special educational needs in the Russian Federation. Revista Espacios, 39(40), 14.

Petrovsky, A.V. (1987) Personal development in the system of interpersonal relations. In: Social psychology. Moscow, 1987. P. 77-90.

Polyakova, L. V. (2000) Distance education. Science and Life, 1, from https://www.nkj.ru/archive/articles/5732/

Tyshkovsky, A.V. (1999) Social and psychological bases of formation and realization of expectations in professional choice and career: Diss. dokt. psychol. sci. Moscow, 481 p. 
Shalimova, A. M. (2014) Social and psychological factors of students' professional expectations. Author's abstract of Cand. psychol. sci diss. Moscow, 25 p. from https://www.dissercat.com/content/sotsialno-psikhologicheskie-faktory-

professionalnykh-ozhidanii-studentov-sotsiologov

Schepens, A., Aelterman, A., Vlerick, P. (2009) Student teachers' professional identity formation: between being born as a teacher and becoming one. Educational Studies Volume 35(4), 361-378. DOI: https://doi.org/10.1080/03055690802648317

Vodennikova, L. A. (2015) Formation of professional value orientations in future special education teachers. Author's abstract of Cand. ped. sci diss. Chelyabinsk, 25 p. from: https://www.dissercat.com/content/formirovanie-professionalnykh-tsennostnykhorientatsii-budushchikh-pedagogov-defektologov

Yaroshevsky, M. G. Petrovsky, A.V. (2002) Psychology. Moscow, Academy, 2002. - 512 p.

Yudina, I., Abramova , N. Kornilova, E. (2017) Organization of Special Education Teachers Training in Conditions of Regionalization of Education (on the Example of the Republic of Sakha (Yakutia). Revista Espacios, 38(55), 10.

Yudina, I. A., Stepanova, N. V. (2019) The role of socially significant projects in the training of speech therapists. World of science, culture and education, 6, 383-385. 